\title{
A Critical Discourse of Singapore's School Geography for the Twenty-First Century
}

\author{
Chang Chew-Hung \\ National Institute of Education, \\ Nanyang Technological University, Singapore
}

\begin{abstract}
School Geography has experienced changes in curricula over the past few decades. In each iteration, the Ministry of Education has endeavoured to design a geography curriculum that is relevant to the needs of Singapore for each of those time periods. Between the 1960s to the late 1970s, it was taught as Regional Geography, covering a range of geographical topics for each selected region. Thematic Geography was introduced in the 1980s to school Geography in Singapore. In 1997, school Geography curriculum underwent changes leading in a new national curriculum at the turn of the century in 2001, in response to a state-driven education initiative- Thinking Schools, Learning Nations. A mid-term review of that curriculum in 2007 resulted in a distinct form of school Geography unprecedented in Singapore's education history. Today, school Geography in Singapore is learnt conceptually with national level assessment designed to that end. In response to the changes in school Geography, pre-service and in-service teacher training has also responded by focusing on conceptual learning and inquiry. This paper will explore the state of school Geography curricula in Singapore today, and the curriculum of teacher training, with the intent to critically discuss if Geography education in Singapore is educating an informed citizen for these changing times. Geography has been a school subject in Singapore since its independence. Although it has remained a disciplinary subject whose place has yet been disputed, the big question of why study Geography in the first place needs to be answered to ensure its continued survival. This paper ends by offering a reason to why Geography plays an important role in education for Singaporeans, and even to any citizen of the world in our changing times.
\end{abstract}

\section{Introduction}

Singapore's education system mandates 6 years of primary and 4 years of secondary compulsory education (a 5 year programme was designed for slower learners). National examinations are held at the end of primary school - Primary School Leaving Certificate (PSLE) and Cambridge General Certificate of Education (GCE) Ordinary Level examinations at the end of secondary education.
Students can gain entry to a junior college for a twoyear pre-university course or a centralized institute for a three-year course upon completing secondary education, with the goal of sitting in the GCE Advanced Level ('A' Level) Examination that determines placement for University entry. Students who are inclined to technical or vocation studies can enroll in the polytechnics or the Institute of Technical Education (ITE). In addition, polytechnic graduates who perform well may study degree courses at the universities while ITE graduates who do well may continue with diploma courses at the polytechnics (See Figure 1 for a detailed map of possible academic pathways for a student in Singapore).

Of each cohort of students enrolled in Primary 1 about $22 \%$ will eventually graduate with a university degree, $40 \%$ graduate with a polytechnic diploma, another $25 \%$ obtain a certificate from the institutes of technical education, and the remainder will enter the job market after secondary school.

The literacy rate for those above 15 years old is 95.7\%. Enrolment in all educational institutions totaled 704, 719 in 2009 with primary schools accounting for 272,254, secondary 217,230, universities 72,710 . There are 29,875 teachers in some 370 primary and secondary schools in Singapore [1].

The education system implemented a major reform in 1997 - 'Thinking Schools and Learning Nation' (TSLN) which "describes a nation of thinking and committed citizens capable of meeting the challenges of the ... 21st century [1]" which led to several initiatives, including nationwide ICT implementation, critical and creative thinking, and National Education. With this reform were several initiatives that were implemented under the concept. These new initiatives include nationwide ICT implementation, critical and creative thinking, and National Education; the last focuses on how to create in Singaporean children the sense of rootedness to the nation no matter where their professions would lead them. This provided opportunities for school students to develop more holistically.

Geography as a subject taught in Singapore schools has undergone several national level syllabi reviews at primary, secondary and tertiary levels through the last 60 years. Today, Geography does not exist as a separate subject in primary school. Rather, it is taught within the subject of Social Studies at primary schools in Singapore [2]. At the secondary school level, Geography is a compulsory subject for 
lower secondary but is an elective subject at upper secondary level. Geography remains an elective subject at pre-university and university education in Singapore.

\section{Primary School Geography}

Between the 1950s and the early 1970s, Geography was a subject taught in upper primary levels (Grades 3 to 6). Subsequently, Geography was taught as an integrated component of Education for Living (EFL) between 1974 and 1984. From 1984, primary school children studied Social Studies as a subject in which Geography was integrated with History. However, in 2000, primary school Social Studies was taught across all Grades $(1-6)$ including components of History, Geography, Sociology and Economics [2].

In 2003, the Primary Social Studies syllabus was reviewed in order to update content and to ensure developmental progression from pre-school to primary school. The syllabus incorporated knowledge, skills as well as attitudes and values essential to the development of a holistic understanding of Social Studies [3]. Of the six years in primary education, students have the opportunity to engage in Geographical knowledge and concepts through social studies in one form or another, through an expanding environment approach. In Grades one to three, the child is progressively introduced to spatial thinking in terms of recognizing his/her immediate surroundings, the school surroundings and the neighborhood. The curriculum is focused on letting students learn about recognizing space and place through simple maps and field excursions to the neighborhood. Grade 4 engages students engaged with the history of Singapore, covering topics of its modern founding and the ethnic mix of early migrants. In Grades 5 and 6, students learn about the bio-physical environment of Singapore and the concept of regions. The latter was achieved by introducing concepts in globalization and the role of multi-lateral relations between countries through organizations like ASEAN.

In essence, primary Geography exists as part of the social studies subject to inform the students' understanding about the human-environment relationship. It is neither a systematic nor thematic study of Geography per se, but rather the spatial and human-environment concepts in Geography are used to help primary schools students understand the world they live in. To this end, 4 themes were proposed in the syllabus document, namely, People, Places and Environments", "Time, Change and Continuity", "Scarcity, Choices and Resources" and "Identity, Culture and Community". The intent of using these four themes was to ensure a continuity and progression of concepts across grades.

However, the concepts in Geography at Primary schools are not made explicit but are often tacitly embedded within the context of social studies. A compounding factor that presents itself as a hurdle to learning geographical concepts well at primary school is that social studies is not a subject tested at the PSLE. Admission to secondary schools and which course of study a student qualifies for is determined by the aggregated score obtained at the PSLE. Given the low stakes in testing, the subject's curriculum time is often cannibalized for drill and practice sessions of higher stakes subjects like mathematics or science [4]. Hence, the challenge is to ascertain the reliability of claims that students who have studied primary social studies have been equipped with geographical concepts based on the understanding of the intended curriculum, at the least. As a counter argument, students' foray into geographical understanding do not end with the PSLE but are instead required to study Geography as a compulsory subject at the lower secondary level in Singapore.

\section{Secondary School Geography}

At the secondary school level, Geography is a compulsory core subject for lower secondary students in the Special, Express and Normal (Academic) Courses. The Express Course is a fouryear course leading to the Singapore-Cambridge General Certificate of Education Ordinary Level (GCE 'O' Level) Examination. The Normal (Academic) Course is a four-year course leading to the GCE Normal Level (' $N$ ' Level) Examination. Students who do well at the ' $N$ ' levels will qualify for an additional year to prepare for the ' $\mathrm{O}$ ' levels. The Normal (Technical) Course is a four-year course leading to the GCE ' $N$ ' Level Examination.

\subsection{Lower Secondary Geography}

While the author does not have documentary evidence for the lower secondary curriculum in the 1970s, anecdotal interviews with fellow Geography educators who were students in lower secondary in the 1970s (1971 to be exact) attest to a more regional focus on learning Geography. The 1956 White Paper on Education Policy to provide a common curriculum to all schools resulted in a new syllabus for Geography for primary and secondary schools in the following year [5]. The syllabus emphasized locational and descriptive information about places and human activities in the world and was essentially a regional syllabus; studying about countries in the world [6]. This regional syllabus was phased out in the 1983 and replaced by a systematic Geography syllabus.

From 1983, a new revised syllabus was implemented for lower secondary Geography which adopted a conceptual framework and focused on concepts, principles and local Geography. The Secondary One syllabus dealt with concepts such as location, direction, scale and environment in Geography with a focus on the Singapore 
environment. The Secondary Two syllabus was centered around the theme of 'Geographical World' and involved with the concepts of interaction, movement and flows, growth, change, hierarchy, decision-making, unity and diversity. Each concept was learnt with examples from Singapore or Southeast Asia.

In the 1990s, the lower secondary Geography was organized around two main concepts "Earth as home for people” in Secondary 1 [7] and "Earth's natural resources and how humans can improve or damage the environment” in Secondary 2 [8]. This deliberate two stage understanding to human-environment concept was useful in that it first engaged the students in understanding the world they lived in before they understood how humans have modified it and what management strategies can be used to mitigate these impacts. However this syllabus too, underwent a curriculum review and resulted in a new syllabus being implemented in 2006 that was focused on a systematic framework to organize content, mainly dividing the topics into Human or Physical Geography topics [9]. The syllabus makes the theme of physical-human relationships explicit while keeping the focus on Physical Geography, Human Geography, geographical skills and issues related to managing the changing environment. It also places greater emphasis on the teaching of geographical skills like atlas skills, map reading skills and photograph interpretation. However, an examination of the topics listed and the way the topics are phrased indicate a more conceptual approach than a systematic one.

For a start, the syllabus was organized into 5 themes. The following lists the themes and the associated topics of study for lower secondary Geography:

1. Introduction to Geography

a. Overview of Geography

b. Earth as Home

2. Understanding the Environment

a. Physical and Human Environments

b. Environments through Maps

c. Environments through Photographs

3. The Physical Environment

a. Landforms and Rocks

b. Rivers

c. Weather and Climate

d. Natural Vegetation

4. The Human Environment

a. Population and Settlements

b. Agriculture

c. Transport and Communications

5. Managing the Changing Environment

a. Land supply

b. Water resources

c. Pollution

d. Global Warming and Ozone Depletion [9]

While the syllabus document articulates a curriculum that adopt a "systematic framework to organize content [9]", it stated that "[w]ithin this framework, the physical-human relationships are used as the organizing theme to show how relationships between people and the environment have given rise to the distinctive character of places and environments [9]”. It is clear that students need to understand the macro concepts in Geography of human-environment, space and place, within this framework. Undeniably this has come a long way from the days where regional Geography was taught. In fact, conceptual understanding of humans and their relationship with the environment was key in lower secondary Geography for at least the past 30 years in Singapore.

\subsection{Upper Secondary Geography}

A cornerstone event in the development of the Geography curriculum for upper secondary is the introduction of the Combined Humanities Subject in 2001. At present all students have to study a compulsory Combined Humanities subject which comprises of 2 papers at the upper secondary level (secondary 3 and 4, or Grades 9 and 10 equivalent). The first paper is Social Studies, which is compulsory, and the second paper, called the elective humanities, can be chosen from the subjects of History, Geography or Literature. Students who study a History or Literature Elective may also opt to study a second humanities subject which can be Geography. Since 2001, a new Geography Elective paper may be offered together with Social Studies as a core elective humanities subject [10].

The topics taught in the Geography elective paper is a subset of the "Pure" Geography subject. This syllabus underwent another review in 2006 resulting in the 2007 Upper Secondary Geography syllabus (Syllabus 2235) which saw a reduction from 10 to 8 topics. It comprises four Physical Geography topics and four Human Geography topics. The topics are listed below with an asterisk to indicate topics that are common to both the elective and pure Geography subjects.

1. Plate tectonics and resulting landforms

2. Weather and climate

3. Natural vegetation*

4. Rivers and Coasts *

5. Geography of Food*

6. The Industrial World

7. Tourism

8. Development*

This syllabus focused on the interaction between peoples and environments. Students need to understand the ingenuity of people could overcome constraints imposed by the physical environment. To that end, each Physical Geography topic is concluded by a study of natural hazards and how humans can manage these hazards. Aligned with the call for engaged pedagogies, there is also emphasis on fieldwork, with suggested fieldwork strategies listed within the syllabus document [10]. Despite the many syllabi revisions over the last 30 years, the form that 
school Geography has taken today is clearly one that requires the conceptual understanding on humanenvironment relationships.

\section{Pre-University Geography}

A similar revision of syllabus was also conducted for the A level Geography subject since 1980s. Currently, Geography is a subject offered in the Humanities and Arts group at the pre-university level. As of 2006, all subjects are offered at three levels, namely Higher 1 (H1), Higher 2 (H2) and Higher 3 (H3) of the GCE 'A' Levels [10]. Students can choose three $\mathrm{H} 2$ content based subject and one H1 subject, where are least one of these are from a contrasting discipline. The two broad groups of "discipline" include Humanities \& the Arts, and Mathematics \& science. So a contrasting discipline means that the student has to study at least one subject from each group and he/she is free to choose the remainder subjects from any of these two groups.

In general, students can study Geography as a H2 subject, but those with deep interest and high ability can pursue the subject at H3 level. Besides the MOEdeveloped H3 Geography comprising a research essay, there are other H3 Geography in the form of university-taught courses and research programme conducted by the National University of Singapore (NUS). The H1 level course is supposed to have the same rigour of academic content with the $\mathrm{H} 2$ courses except that it is half of a $\mathrm{H} 2$ course in terms of curriculum time [11].

The core topics in Geography at pre-university level focus on the themes of physical-human relationships and human organisation of space. There are three Physical Geography topics and three Human Geography topics.

1. Lithospheric Processes, Hazards and Management

2. Atmospheric Processes, Hazards and Management

3. Hydrologic Processes, Hazards and Management

4. The Globalisation of Economic Activity

5. Population Issues and Challenges

6. Urban Issues and Challenges

The H1 Geography syllabus (Syllabus 8812) consists of three of the six topics in H2 Geography syllabus. The two compulsory topics are Lithospheric Processes, Hazards and Management and The Globalisation of Economic Activity. The third topic is a choice of Hydrologic Processes, Hazards and Management or Urban Issues and Challenges. Again, the more recent syllabi are focused on a more conceptual understanding of humans and their relationship with the environment.

The evolving syllabi in school Geography at primary, secondary and pre-university levels over the last 3 to 5 decades have moved from regional studies of Geography to conceptual understanding of the relationship between humans and their environment within the context of space. However, the success of the intended curriculum in school Geography depends on its implementation in the classroom. Teachers are the most important curriculum gatekeepers as they are at the "front-line" of teaching and learning.

\section{Geography at the university}

The Universities in Singapore are the NUS, Nanyang Technological University (including NIE), and the Singapore Management University [1]. Geography as a subject of academic studies exists in one department at the NUS and one department at NIE.

At NUS, a wide range of courses are offered [12] with only one of the first year courses and another methods course being made compulsory, and some pre-requisite of higher level courses. This first year course is on Place, Environment and Society and students can read one methods course from one of Introduction to GIS and Remote Sensing, Methods and Practice in Geography, Applications of GIS and Remote Sensing, Field Studies in Geography: SE Asia or Environmental Research Methods. While there is a fixed structure of graduation requirements, students have a wide choice of modules to choose from, apart from a compulsory introductory course and a methods course. While the wide range of courses offered reflects the research interests and strength of the department, there is no apparent structure to ensure that the undergraduates have equal opportunity to engage in Human Geography, Physical Geography and methods courses which are important for building the subject matter knowledge that will inform pedagogical content knowledge for teaching school Geography.

The other university department offering Geography as an academic subject of study is the National Institute of Education (NIE), an autonomous institute of the Nanyang Technological University (NTU). It is the sole teaching training institute in Singapore and offers a Bachelor of Arts (Education) programme as one of the several pathways to gain teacher certification.

\section{Teacher Preparation and Professional Development for Geography}

The main body of certification for all practicing teachers in primary, secondary and pre-university schools in Singapore is NIE. Started in the 1950s as a Teachers' Training College, NIE went through several restructuring exercises and became an autonomous institute of the University in 1991. NIE provides both pre-service and in-service training for teachers in three main areas of academic subjects, education studies and curriculum studies. Geography curriculum studies subjects are taught by the Humanities and Social Studies Education Academic Group. There are two programmes for pre-service 
teacher training in which Geography curriculum studies is undertaken, namely the Bachelor of Arts (Education) degree and the Postgraduate Diploma in Education.

The Bachelor degree programme (4 year programme) requires a student to read one academic subject for Primary school teaching (single major) or two academic subjects for Secondary School teaching. In addition, a student reading Geography for Secondary School teaching may choose it to be the first or second academic subject, similar to a Major or Minor specialization programme. Students reading Geography as academic subject 1 (AS1) has to complete 4 years of academic subject training in that subject but Geography minors only need to complete 2 years. The curriculum is similar for all major and minor Geography students up to year 2 at NIE.

In the first year of study, students are required to read four compulsory courses. These include the introductory courses to Physical and Human Geography, Techniques in Geography and a course on Singapore in Asia. In second year, students can choose from a range of courses but they have to read at least one human and one Physical Geography course. In the third year of study students can choose to read any 4 courses from the range provided. In the fourth and final year, students are required to read a course designed around a compulsory overseas fieldtrip. A report has to be produced by the student which will then be assessed. The fieldtrip course and report provides the students the opportunity to integrate the learning over the four years into a single coherent geographical inquiry. The intention for a fixed structure on the students' choices in years one and two is to ensure that students are provided with the subject matter knowledge and academic rigour required of a trained teacher to engage with the national curriculum for school Geography. The final year field trip course provides the students with an opportunity to experience Geography on top of learning about it in a classroom context.

The Postgraduate Diploma in Education is a 9month programme for teacher trainees who have already obtained a University degree with Geography as a Major subject of study. These teacher trainees only read education studies and curricular studies as their undergraduate training obtained elsewhere is assumed to have equipped them with sufficient subject matter knowledge.

In both the Bachelor and Postgraduate programmes, the training in curriculum studies focuses on three aspects,

1. Planning to teach Geography

2. Fieldwork in Geography

3. Assessment in Geography

The context of the secondary and pre-university Geography curriculum in schools is used to teach the three aspects above. To address the needs of school teachers, who "remain focused on textbooks as a means of instruction in the class [13]”, the training is designed to help students decide what they need to teach; What is good to teach, what is important to teach and what is crucial to teach. To that end, preservice teacher training for a Geography Teacher required them to ask the "what", "why" and "how" of curriculum planning and instruction.

To this end, the Understanding by Design (UbD) conceptual framework (also called the backward design process) was used whereby the teacher trainees think about assessment before deciding on what and how to teach. Consequently, this process requires a clarification of the desired results of instruction before deciding on how the instruction should be designed. The framework is broken down into three stages for easy understanding:

Stage 1: Identifying desired results

Stage 2: Determining evidence of learning

Stage 3: Planning the learning experience (instruction).

In order to assist teacher trainees use this framework for planning how to teach, there was a need to develop a strong conceptual understanding of the subject matter, in addition to the teacher trainee playing the role of a curriculum designer and knowing who the learners are.

The teacher trainees were given a task of designing a unit of instruction on one of the themes in the current school Geography syllabus for upper secondary school. At the start of the course, the unit plan was developed before they were introduced to the concepts. This draft is then revised and reworked as they acquire the skills involved in planning the unit.

Teacher trainees clarify the desired learning goals by "identifying the essential questions and enduring understanding of the curriculum units [13]". Here the disciplinary understanding of the concepts in Geography helps them make connections within and across the units. This is where the teacher training programme ensures relevance to changes in academic Geography. Teacher trainees have to develop concept maps for the school Geography topics based on their prior academic training. This is where their previous engagement in academic Geography takes center stage in informing their understanding of concepts in the school curriculum.

In addition, they are guided to craft performance tasks and the corresponding criteria for evaluating the task performance, which form the evidence of understanding. Finally, the teacher trainees design the learning experiences to achieve the desired outcomes. As part of understanding if the teacher trainees have understood the principles, they have to present their entire unit plan package to the tutors and undergo an oral defense of why the unit was planned the way it was. This process affords the teacher trainees opportunity to see their "own personal growth in designing unit lessons [13]". Also, misconceptions or lack of understanding of the 
subject matter knowledge of Geography can be elucidated through this reflection on their prior academic Geography training.

There is conscious effort to align the conceptual approach in pre-service teacher training and the requirement of understanding the concepts that underlie the topics in the school Geography syllabus to the in Geography academia. In addition, the need to update existing teachers to the changes to academic Geography and developments in Geography education was undertaken through inservice teacher courses. NIE is a major provider of teacher in-service courses in Singapore. As the Ministry of Education provides funding for Professional Development (PD) for teachers, they have also mandated a 100 hour PD time [14]. As a result, there was a proliferation of PD courses in Geography subject areas in the mid to late 2000s. There are two main types of in-service Geography courses offered by NIE, namely, content and pedagogy courses.

1. Courses on Knowledge and Skills in Geography

a. Lectures in Upper Secondary Human Geography

b. Lectures in Lower Secondary Geography

c. Research Technique in Human Geography

d. GIS made simple for Geography

e. Fieldwork for Geography

f. Selected Aspects of Atmospheric Processes for "A' level Geography

g. Selected Aspects of Lithospheric Processes for "A' level Geography

h. Selected Aspects of Hydrologic Processes for "A' level Geography

i. Transport and Communication And Managing The Changing Environment For Lower Sec Geography

2. Courses on Pedagogies for Teaching Geography
a. Exploring Geography through Inquiry
b. Alternative
Assessment in
Geography
c. Big Ideas in Geography
d. Web 2.0 Tools for Geography
e. Teaching Map Reading
f. Teaching Map Reading through IT
g. Field and Laboratory Instruments in Physical Geography
h. Learning Physical Geography through Movies

The purpose of these courses is as implied in the categorization, courses that provide teachers the opportunity to update their content and pedagogy in teaching Geography. As a University institute, Geography teachers also have the opportunity to pursue Higher Degrees or Advanced Diplomas to deepen their academic studies in Geography. In particular, a Professional Development Curriculum Model (PDCM) was developed by NIE to provide a clear articulation of the academic pathway for teachers to pursue higher degrees [14]. Together with the spread of in-service courses, higher degree opportunities afford Geography teachers multiple means of updating content and developing their pedagogies, even if they have graduated from their undergraduate degrees years ago.

\section{Theory into practice for training Geography teachers}

An added feature of the undergraduate preparation of Geography teachers at NIE is the strength of teaching both the academic as well as curriculum studies about Geography. Geography student teachers are engaged with applying the academic understanding of the discipline to interpreting the school curriculum and planning instruction and assessment.

A wide range of pedagogies is used to teach these academic and curriculum subjects in Geography, in order to model and practice the pedagogies taught. Instructional approaches used include and are not limited to cooperative learning, inquiry based learning, differentiated instruction, Socratic questioning and using Information and Communication Technology (ICT). For example, students have to keep an electronic portfolio on which they collect pieces of work and reflections, which they then have to pull together into a showcase portfolio to show their practicum supervisors their strengths, so as to facilitate more meaningful practicum supervision. Another example of using ICT in Geography teacher training is the use of Web 2.0.

\section{Technology and its role in training Geography teachers}

The 2.0 in Web 2.0 suggests that there is improvement or enhancement to the web as we knew it. Instead of on-demand access of information, Web 2.0 allow users to do more than just retrieve and receive information by incorporating RSS feed technology which pushes information to the user. In essence, this results in Web 2.0, which incorporates three distinctive components of participation, collaboration and distribution. Web 2.0 collects among other things, existing and emergent technologies such as blogs, wikis, podcasts, multimedia sharing and content creation tools, bookmark sharing and social networking software. Participation in activities using these tools results in content creation, often through collaboration with other Web users.

Inherent in these three main features of Web 2.0 is the potential for inquiry in teaching and learning, which is aligned to the approaches used in training Geography teachers at NIE. For example, blogs are 
particularly useful for reflection and wikis allow for group projects and new ways of working collaboratively. Web 2.0 allows greater student independence and autonomy, and greater collaboration.

In the teacher-training course for Geography teachers at NIE, a very important component of the programme is reflections. While the course has been traditionally conducted through workshops whereby the student teachers are exposed to a hands-on approach, where learning is by doing rather than by knowing, the onset of Web 2.0 extended opportunities for reflective learning. While several technologies of Web 2.0 were being used the example of using Blogs will be included here for discussion.

\subsection{Blogs and Reflections}

As part of the Geography curriculum course, student teachers are required to blog about their reflections throughout the course. Each student teacher sets up his or her own blog and sends the RSS link to the trainer. The trainer then uses a feed aggregator on iGoogle ${ }^{\mathrm{TM}}$ and published them. The page address is then sent to all student teachers that will then be able to view the latest updates on each other's blogs. Apart from making comments on each other's reflection, the student teachers often publish new discoveries in terms of resources or lesson ideas. In addition to student teacher reflections, the trainer also publishes reflections after every session on his blog. To vary the medium of expression, podcast episodes of the blogs are also introduced in this extension of the teacher training programme. Through the interaction between student teachers and trainer, and among student teachers, some interesting insights into teaching practice emerge. Two anecdotes are included here to illustrate the benefits of using Web 2.0 in reflection on teaching training.

As part of pre-service training programme for Geography teachers at NIE, the course on planning for instruction uses the "Understanding by Design" framework. Inherent in this approach will be the need to design performance tasks to gather evidence for learning. And as a guide to designing these performance tasks, our student teachers were taught to elucidate the Goal, Role, Audience, Situation, Product, and Standards for evaluating performance (GRASP format) in the task they design. One student commented on what he has learnt so far and used the analogy of a martial arts student. While the martial artist has learnt many moves in training, the real test comes when he has to execute the moves in a single fluid process, in response to the moves rendered by his opponent. Thus it is the overall experience of the moves rather than focusing on the steps that is important in this learning process. His lament was that the steps constrained him more than is helped him in designing the task. The trainer, pointing out that without those small steps, the martial artist would not be able to execute the moves properly even if he had the big idea. Several comments from other students followed but it did not end online. This then led to a full half an hour discussion on how important it was to follow the GRASP format, in class the next day. At the end of the class discussion, the student teachers felt that while the GRASP format was tedious to follow, it was an important scaffolding tool for beginning teachers.

In this case, the online interaction was rapid and engaging simply because, the information was almost immediately available to the participants. As everyone in the class has subscribed to the RSS feeds, this allowed all the participants to be informed of latest postings with a short digest of the posting on his or her own feed aggregator. As the content of the feed was relevant to the student teachers, they responded by participating in the discussion. The overflow of discussion into the class time the next day was a further indication that the topic was of high relevance to their training. After the class graduated from the programme the trainer is still in contact with the group through Facebook ${ }^{\mathrm{TM}}$, and the discussion and sharing on teaching practices continues to this day.

In another example, one student commented that a learning point from one of the field inquiry classes was that Geography involved fieldwork because it was really about "feel” work. He suggested that field inquiry required the use of the five senses and this was considered crucial to understanding the physical and human environment. In the proliferation of comments on his post over the next few days, an interesting insight provided by his course-mate was that fieldwork should not be "fill" work in which students had to fill out worksheets while learning in the field. Again, this provided an opportunity for class discussion and reflection during the following lessons.

The use of ICT in training Geography teachers is mainly through providing a platform for the students to reflect on their understanding of the practice and then refine it. It follows that if the training that teachers received are well supported by ICT, then a reflective teacher will be able to consider how ICT can be effectively use in his or her classroom. While there is yet an empirical study to document the extent of ICT use in teaching and learning of Geography in classrooms in schools, anecdotal accounts are abundant on ICT use in Geography classrooms. A survey needs to be carried out to determine how pervasive such pedagogical practices are in schools, so as to inform review of Geography teacher training curriculum in future.

Despite the positive tone of the sections delineate above, the question of what are some problems that Geography education face in Singapore and what can be done about it remain unanswered. While Geography has survived as an intact subject within school and university thus far, there is no ensuring that this situation will continue. The following 
section highlights an important aspect of Geography education that should be considered in a world where environmental changes are occurring at unprecedented rate, scale and complexity.

\section{Education for sustainable development (ESD) in the curricula}

Inherent in the concept of sustainability is the idea that development should be kept apace so that future generations' development will not be compromised. Without education, an important process to pass on and propagate ideas and to inculcate beliefs about what constitutes sustainable practices to our future generations, there is little hope for sustainability. Humanities subject such as Social Studies and Geography take centre stage, as ESD is not present as a subject nor featured strongly in the core curriculum in Singapore.

Lidstone and Stoltman [15] propose that there is a need to "conduct comparative research on how Geography curricular in various countries" are addressing sustainability concerns. Singapore's Geography curriculum feature ESD strongly in the lower secondary and pre-university levels. In fact, ESD is present only in Geography and Social Studies. There is little evidence of ESD in History or Literature.

The Geography Curricula will be divided into the following categories for the purpose of analysis:

1. Lower Secondary Geography

2. Upper Secondary Geography (Pure \& Elective)

3. Pre University Geography (H1 \& H2)

At Lower Secondary, the Geography Curriculum is organized around the themes of understanding the environment to managing the changing environment. It reflects an approach that is centered on providing the core knowledge about environmental concerns of our times. In particular, the concern of climate change is included in the concluding unit of the curriculum. Apart from the knowledge of the causes and impact of global warming, students are expected to learn how to describe and evaluate the measures to reduce the impact of global warming induced climate change. In addition, students will develop attitudes such as accountability, social responsibility and personal care and concern for the environment. At a glance, the knowledge, skills and values for this unit address the core concepts in ESD. It provides opportunities for teachers to move students from an awareness phase into a taking action phase, assuming that the values are well learnt.

ESD on climate change is only present in the "pure" Geography subject at the upper secondary level. The unit on "Weather and climate" features a section on "climate disasters". Only the knowledge about the impact of climate change related phenomena is included here. There is no explicit mention of skills or values that should be learnt with respect to climate change concerns. In as far as ESD is concerned, this has to be addressed in the Geography curriculum.

At the pre-University level, ESD on climate change is only featured at the $\mathrm{H} 2$ level. Under the Unit on Atmospheric Processes, Hazards and Management, the section on Climate Change and Responses is organized around the issue of the problems brought about by global warming induced climate change. In particular, the section includes knowledge, skills and values that are central to ESD. The section requires students to learn the causes, impact and adaption and mitigation strategies of global warming induced climate change. In addition skills such as describing and assessing these strategies are required. Values that are relevant to the issue include Adaptability and Preparedness for any eventuality. Similar to the lower Secondary Geography curriculum, the knowledge, skills and values for this unit target the core concepts in ESD. They allow the students to move from awareness to taking action. While there is no immediate apparent follow-through of the concerns on climate change from lower secondary to upper secondary Geography syllabi in terms of skills and values, the absence is probably intentional as the social studies (which is a compulsory subject) syllabi has a distinct section on environmental concerns for both the lower and upper secondary levels.

In terms of exposure to ESD in the formal curriculum, a student in Singapore comes into contact with concepts of ESD as early as Primary 3 (9 years old) through Social Studies. The knowledge, skills and attitudes are explicitly taught at lower secondary for both Geography and Social Studies. At upper secondary level, Social Studies is the main delivery mechanism for ESD. At pre-university level, Geography becomes the main subject through which ESD on Climate Change is achieved. However, only when our students move from mere awareness of sustainability concerns to interpreting, analyzing and studying the issues and then finally developing some personal opinion and attitude about these issues, can we hope that sustainability for the future can be achieved. In other words, action and not just inculcation is key to the successful implementation of ESD.

It is important for Geography curriculum in schools to address beyond the knowledge and skills of Geography into the values we desire our students to develop so as to take action to ensure sustainable development in the future. But how do we know if students have learnt values? Fundamentally, what type of skills will support the development of values? If we desire our Geography students to be informed and critical citizens, then a skill required must be the ability to evaluate information surrounding a geographical issue. In other words, how will the existing mode of national level paper and pen examinations help educators understand how much students have learnt about how to evaluate issues? 


\section{Assessment in School Geography - Is it for ESD?}

A reviewed Singapore secondary (high-school) Geography curriculum was implemented in 2007 [10] in which a new marking approach was employed for part of the national written examination paper. The "levels marking" approach was implemented with the goal to assess students' ability to discuss geographic problems and to construct arguments for evaluating these problems. This resulted in much anxiety among some teachers, as the "point-marking" approach was the modus operandi used for Geography assessment in Singapore for the last few decades. With this change, questions on what type of pedagogy best affords the "levels-marking" approach have been raised across the geographic education community from teachers to education researchers in Singapore.

According to Sellan, Chong, and Tay [16] the changes to the assessment mode, in which levels marking is first introduced to the Geography Curriculum in Singapore, are to prepare students "to meet the challenges of an increasingly globalised world ... to promote critical and creative thinking skills, and to nurture problem-solving and independent learning abilities in students." For the past 2 decades, the assessment format of the Geography GCE "O" Level examination has comprised two examination papers. Paper one was a multiple choice paper consisting of 40 questions and Paper two consisted of up to a dozen structured essay questions, of which students chose to answer four questions. The structured essay questions were marked using a point-marking scheme in which marks were awarded for relevant and accurate points raised in answering the given question. In the new syllabus, the examination paper consists of one Physical Geography paper and one Human Geography paper. Both papers consist of 4 essay questions, from which any two are answered. The last 8 marks of each essay question are allocated to a sub-question, which requires some degree of application, comparison and evaluation. This is the part of the question that is marked using the levels marking approach.

If the Geography curriculum is intended to be a vehicle for ESD, then this development in the assessment format at a national level examination is a welcome change. Not only will it force students to analyse the information they have to provide, they will have to evaluate the issue and then provide an opinion. As mentioned, the ability to evaluate information surrounding a geographical issue is a necessary condition to develop Geography students who are informed and critical citizens. This is a necessary but not sufficient condition.

\section{The future of Geography in Singapore}

In order for Geography to remain relevant, it must address the issues of our time. ESD plays a pivotal role in ensuring that Geography is able to engage our students in the knowledge, skills, values and actions that are required to respond to the unprecedented changes to our lived environment in terms of rate, scale and complexity.

Although the sections above delineated how Geography has remained largely relevant to the needs of Singapore through the past few decades, there are several issues that need to be considered for its ensured survival as an uncompromised subject at school and at the university. Increasingly, the problem of falling student intakes for Geography at Universities has raised concerns as they eventually form the pool of Singapore's Geography teachers in future. With a diminishing pool of Geography teachers, the challenge of inspiring more students to learn geography at school and at the university through good teaching practice becomes more arduous. While this is a challenge exacerbated by an aging population, there is a real problem of motivating students to study Geography if they do not see its relevance to their lives. A new syllabus is being drawn up and planned for implementation in the next few years as a review of the existing syllabus. What is heartening is that the syllabus review process is highly consultative and involves stakeholders such as teachers, curriculum planners, university academics, as well as teacher trainers. However, it is equally important for this group to recognize the importance of grounding the syllabus in real world issues and in developing opportunities for students to translate the knowledge, skills and values into action. Only then can the subject be relevant to the lives of our teachers and students.

Fortunately, the education ministry has the insight to develop human capital to respond to this challenge. The Academy of Singapore Teachers, which was set up with the purpose of raising teacher professionalism, will be working with NGOS like the Southeast Asian Geography Association [17] and the Geography Teachers' Association, Singapore to advance their work on a Geography Chapter in which, the goal is to develop a network of Geography teachers that can come together to reflect and recharge. As the network is only in its infancy, the efforts will be futile if the interaction does not extend into discussions on issues that affect our daily lives.

\section{Conclusion}

While the state of Geography education has undergone development that is in alignment with the needs of the nation and for students to stay relevant in a $21^{\text {st }}$ century world, the argument presented here for its continued survival rests on developing a 
Geography that is relevant to our lives [18]. Indeed, a milestone project of the Geographical Association called "Living Geography" proposes that student should be engaged with "innovative and enjoyable learning that embraces his or her own perceptions of change in the local environment" [19]. To that end, Living Geography argues for Geography curricula that are current and future oriented, local but set in the global, investigate change processes and evaluate change and question sustainability [19]. In particular, the idea that the learning at a local scale is set within a global context is appealing to the argument for a geography education that prepares the learner for the needs of our times. Indeed, this is the very idea that the paper has argued for thus far. Through examining the historical development of school Geography, Geography at the local Universities and the changes to the teacher-training curriculum in Singapore, examples of practices that support this idea have been discussed. Conceptual learning and the changes to assessment modes provide the necessary conditions for students to take action for the world they live in. There is no guarantee that students will see this relevance or even want to do anything about climate change, for example. However, teachers are important change agents who do not just carry out the curriculum, but through their own reflective practice and beliefs, inspire the students they teach. Perhaps the first step is for Geography educators themselves to model the action they would like to see in their students. Geography educators need to answer the big question of why study Geography in the first place through action, and explicate it in Geography curricula in schools, at the University and for teacher training. As Geography plays an important role in education for Singaporeans, and even to any citizen of the world in ensuring that future development is sustainable, its relevance cannot and should not be easily dismissed.

\section{References}

[1] Department of Statistics, Ministry of Trade \& Industry (2010) 'Singapore Yearbook 2010'; http://www.google.com/url?sa=t\&source=web\&cd=4\&ved =0CDEQFjAD\&url=http\%3A\%2F\%2Fwww.singstat.gov.s g\%2Fpubn\%2Freference\%2Fyos10\%2Fyos2010.pdf\&rct=j \&q=singapore\%20yearbook\&ei=1Z5QTZDXB83hrAfqze3 bCA\&usg=AFQjCNHsSIJV_pjJQI45TDT-

EeWu1GP3EQ\&sig2=Afe1U8-aXLqj7FwVJ (2 January 2011).

[2] Fang, S. (2002) A historical development of the primary social studies curriculum in Singapore, National Institute of Education, Nanyang Technological University, Singapore.

[3] Curriculum Planning and Development Division (2006) Social Studies Syllabus - Primary, Ministry of Education, Singapore.
[4] Lo, J. (2010) 'The primary social education curricula in Hong Kong and Singapore: A comparative study', HKIEd Research Repository; http://libir1.ied.edu.hk/pubdata/ir/link/pub/RCIE\%20HK\% 20and\%20Singpaore_\%20revised\%209\%20Feb\%2010_.pd f (4 January 2011).

[5] National Library Singapore (2009) 'On educational systems and programmes from 1800s to present', NLS Resources;

http://libguides.nl.sg/content.php?pid=57257\&sid=460807 (2 January 2, 2011).

[6] Apple, M. W., \& Aasen, P. (2003) The State and the Politics of Knowledge, Routledge, New York.

[7] Curriculum Development Institute of Singapore (1995) Understanding Geography 1, Longman, Singapore.

[8] Curriculum Development Institute of Singapore (1996) Understanding Geography 2, Longman, Singapore.

[9] Curriculum Planning and Development Division. Lower Secondary Geography Syllabus. Singapore: Ministry of Education, 2007.

[10] Singapore Examinations and Assessment Board (2010) 'GCE O-Level Syllabuses - Combined Humanities 2192', Singapore Examinations and Assessment Board; http://www.seab.gov.sg/oLevel/2011Syllabus/2192_2011.p df (3 January 2011).

[11] Ministry of Education (n.d) 'Our Education System', http://www.moe.gov.sg/education/ (3 January 2011).

[12] National University of Singapore (2006) 'Undergraduate Modules', Department of Geography; http://www.fas.nus.edu.sg/geog/programmes/und_lev_all.h tml (25 April 2006).

[13] Tan, I., and Lay, C. (2007) 'Teaching For Understanding: Designing Curriculum for Instruction Using the Understanding by Design Framework for Geography Teachers' Pre-service Education', in Geographical Views on Education for Sustainable Development Proceedings, Reinfried, S., Schleicher, Y. and Rempfle, A. (eds.), International Geographic Union: Lucerne, pp. 94 - 101.

[14] Tan, S., Wong, I., and Goh, C. (2010) 'Strategic Teacher Professional Development" in Transforming Teaching Inspiring Learning - 60 Years of Education in Singapore 1950 - 2010, Ai, YC and Siew, LK (eds.), National Institute of Education, Singapore, pp. 147 - 158.

[15] Lidstone, J. and Stoltman, J. (2007), "Sustainable Environments or Sustainable Cultures', International Research in Geographical and Environmental Education, (16)1, pp. 1 -4.

[16] Sellan, R., Chong, K. and Tay, C. (2006) 'Assessment Shifts in the Singapore Education System' Singapore Examinations and Assessment Branch; http://www.iaea2006.seab.gov.sg/ (30 March 2008). 
[17] Poh, A., and Nadarajah, V. (2010) 'Pioneering Teacher-Led Professional Development of Geography Teachers', Southeast Asian Geography Association; www.seaga.info (15 January 2011).

[18] Lambert, D. and Morgan, J. (2010) Teaching Geography 11-18: A Conceptual Approach, Open University Press, London.

[19] Geographical Association (2010) 'Living Geography’, Geographical Association;

http://www.geography.org.uk/projects/livinggeography (15 January 2011). 


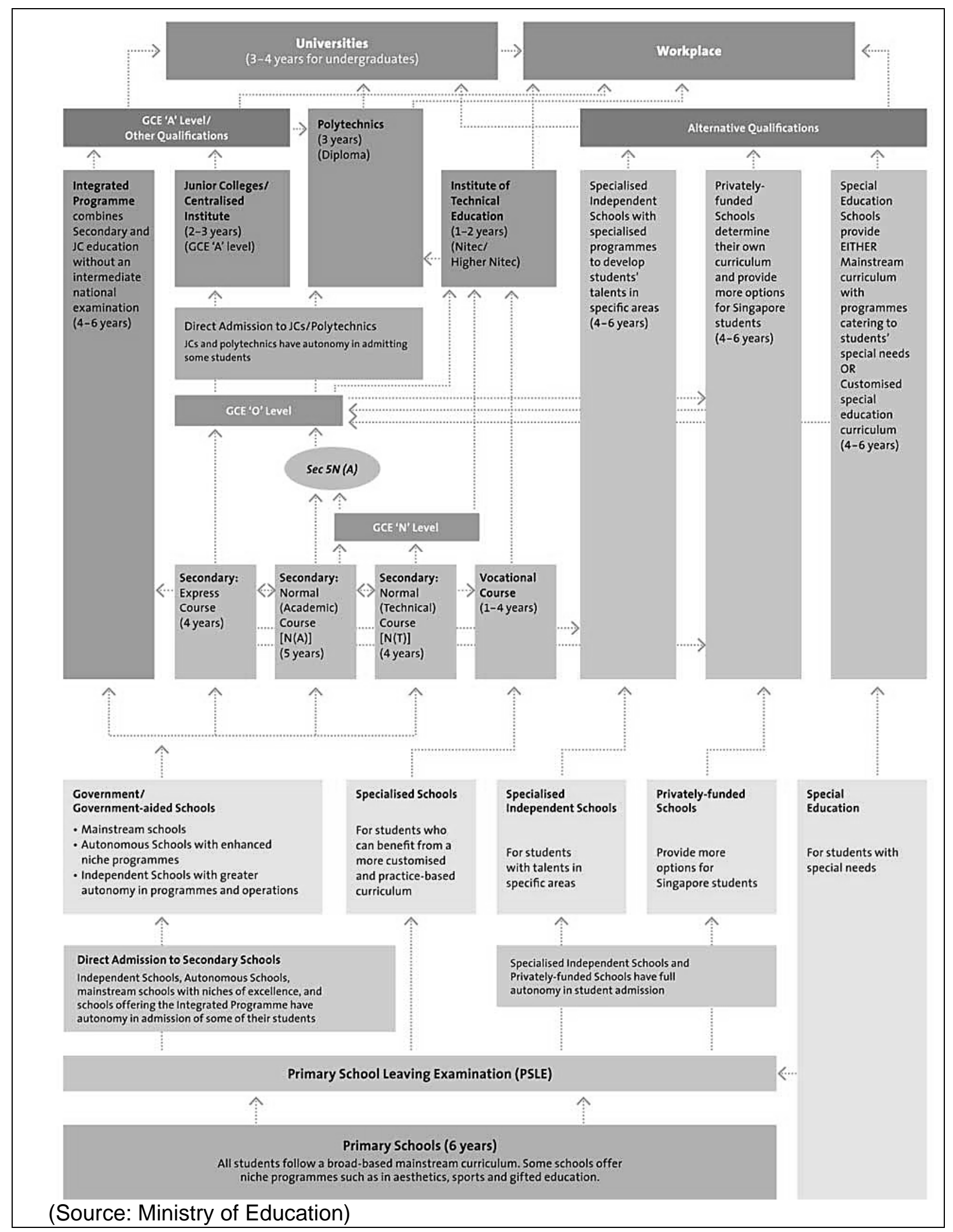

Figure 1: Pathways for Students in the Singapore education system 


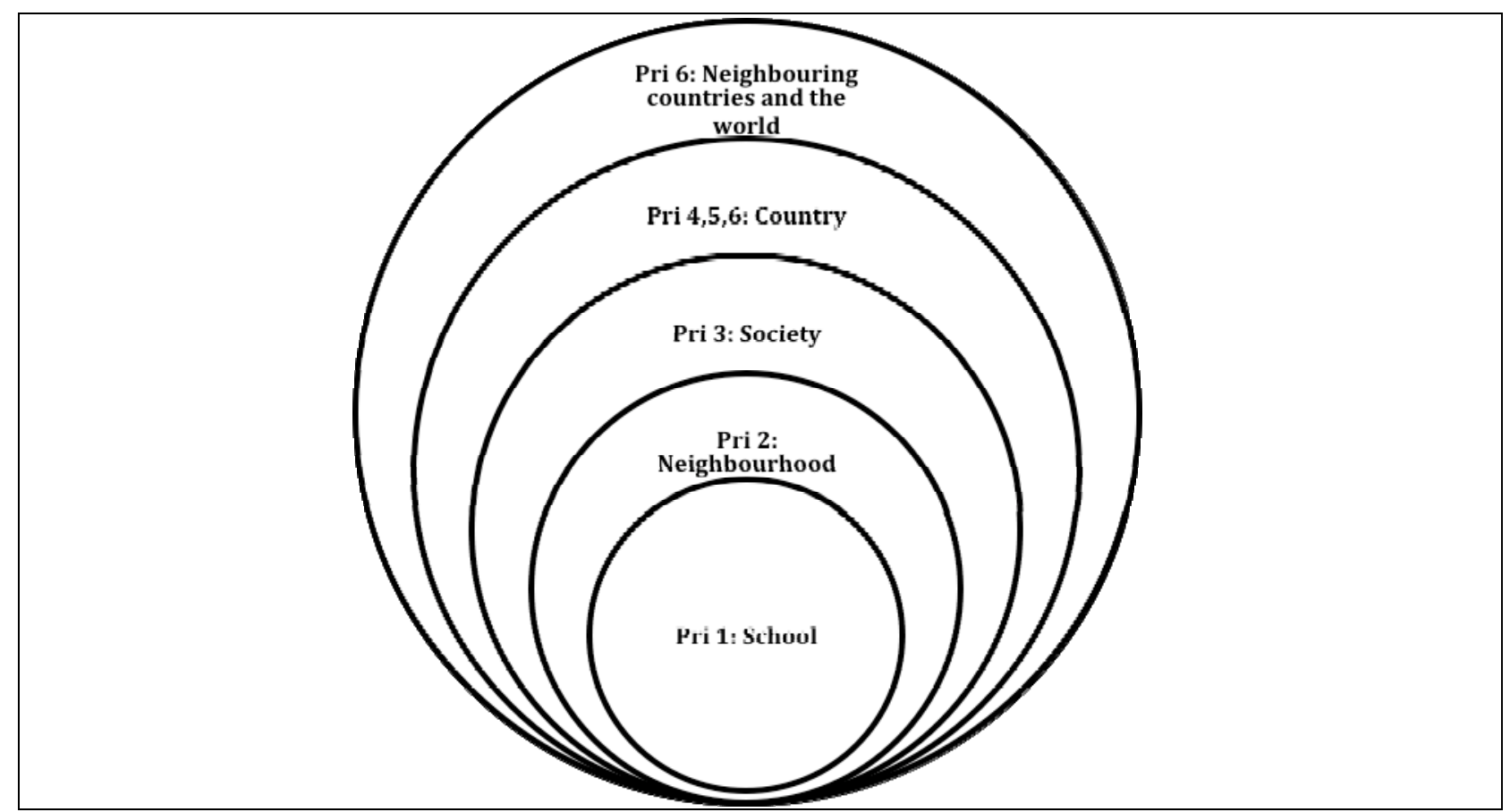

Figure 2: The expanding environment approach in primary social studies in Singapore

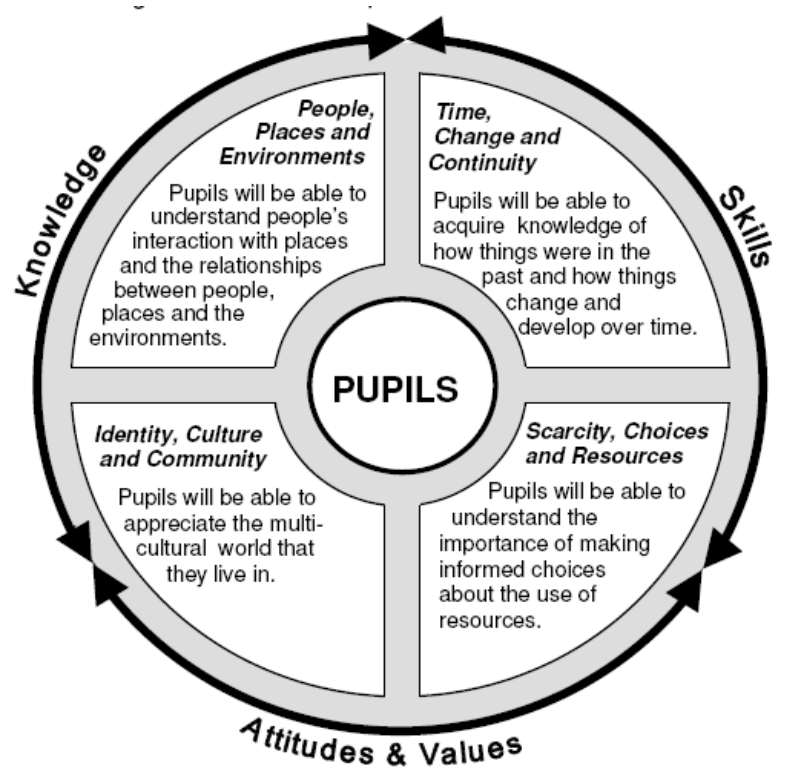

Figure 3: Conceptual approach to understanding concepts in Primary social studies. 